\title{
Discourse Strategies in English Language Pedagogy during the Practicum: A Comparative Study of Student Teachers in Bungoma County Secondary Schools in Kenya
}

\author{
Napwora Wekesa Jesse ${ }^{1}$, Benter Oseno Gudu ${ }^{2}$ \\ ${ }^{1}$ Kibingei Friends Secondary School, P.O Box 214-50204, Kimilili - Kenya \\ ${ }^{2}$ Moi University, P.O Box 3900-30100, Eldoret - Kenya
}

\begin{abstract}
Teacher effectiveness improves students' learning outcome. Therefore, this paper sought to investigate teacher effectiveness in the use of discourse decision making strategies in English language lessons. The objective of the study was to i) examine the role of practicum length on English language student teachers' classroom discourse strategies, ii) student teachers' pedagogical effectiveness in the classroom by comparing their classroom discourse decision making strategies in the first half of the practicum (May-July 2014) and the second half of the practicum (September- November 2014). The study adopted mixed methods design, case study method. The classroom research involved two student teachers of English from a Public University and a Public Diploma Teachers College who were on practicum for one and two terms respectively. Purposive sampling was used to identify the two teachers who were on practicum. The data was collected using four data generation techniques; observation, supervisor's notes, interviews and tape recording. The data was transcribed, coded and analyzed descriptively using SPSS computer package and qualitatively basing on the emerging themes. The findings include modification of grammar, balance in the use of convergent and divergent questions, improvement in wait time, improved student participation and collaborative learning. The findings have policy implication in English language teaching field and stakeholders including pre-service teachers, teachers of English language, language educators and curriculum designers
\end{abstract}

Keywords: practicum, discourse strategies, student teachers, English language

\section{Introduction}

Practicum is the field placement of the student teachers (Onge'ondo, 2009). It is any portion of teaching ranging from micro teaching, teaching an individual lesson and to a sustained practicum over which the student teacher has direct control. Practice teaching can occur as part of a formal teacher education programme or it can be part of an -on -the job, orientation or development effort as long as there is someone who fulfills the function of teacher educator in that context (Richards, 1990:105). These two definitions may apply to practicum in one way or another. Research on practicum has shifted from concern with finding how best the student teachers are succeeding in imitating the perceived "best" practices of the experienced colleagues (Stone and Morris, 1972) to a major expansion in focus covering related and sometimes overlapping topics such as student teacher learning during practicum, support by cooperating teachers and supervision. Research done on Practicum has covered several areas including student teacher collaboration (Ongeondo, 2009), beliefs about language learning (Debreli, 2016), wait time (Singh and Hashim, 2014), factors enhancing student active participation (Critelli and Tritapoe, 2010). However, there has been little if any or no research in the role of practicum length on English language student teachers ${ }^{\text {ee }}$ classroom discourse strategies in the Kenyan context.

\subsection{Student Teacher Learning}

Ongeondo (2009) observe that research on student teacher learning during teaching practice has covered such areas as student teacher's main concerns, student teacher"s experiences, what and how student teachers learn and how specific innovations by particular universities contribute to teacher learning. Moreover, research has also shown that most student teachers are initially more concerned with their own survival in the classrooms and how to control the learners than how they could facilitate the learning of their own students (Kagan, 1992; Borg, 2006). Numrich (1996:135) in Ongondo (2009) found that student teachers on practicum realized challenges of supporting their students ${ }^{e c}$ learning. He says:

During the first weeks of the practicum, teachers were pre-occupied with their own teaching. Little if any mention was made of the students ${ }^{\text {ee }}$ needs or learning in their studies.

However, such studies have also shown that with time especially if the practicum session is extended (about one year) and if the student teachers are well supported (worked closely with their co-operating teachers and teacher educators), then they are able to make quick progress from primary concern with survival to thinking about how they could facilitate learning among their own students (Tann, 1994). However, research in this area is lacking for any meaningful intervention to be put in place. Researchers have also explored the question of how student teachers learn and fail to learn during the practicum. Research indicates that they learn skill of planning and ability to make instructional decisions (Johnson, 1992; Kohler, et al, 2008; Dellicarpini, 2009).

\section{Volume 6 Issue 1, January 2017




\section{International Journal of Science and Research (IJSR) \\ ISSN (Online): 2319-7064}

Index Copernicus Value (2015): 78.96 | Impact Factor (2015): 6.391

Recent researches have indicated that student teachers face many challenges during practicum for instance understanding classroom dynamics, scheming and lesson planning, implementing lesson plans and learners ${ }^{\text {ee }}$ cultural dynamics (Scheeler et al, 2004; Genc, 2016; Gudu et al, 2016). In addition, Kohler et al, (2008) report that student teachers in their studies were not able to give clear explanation for the decisions they made during teaching. Prolonged practicum length may offer student teachers with opportunities for practice and hence could improve in their decision making.

Practicum remains an important vessel that enable student teachers to improve their teacher efficacy especially when the practicum is extended (lasting about one year) and well supported involving close collaboration among students teachers, co-operating teachers and teacher educators (Onge'ondo, 2009; Atay, 2007). A research done in England by Bradfield and Hudson (2012) identified the four main facilitators in teaching and learning during practicum which include teachers, peers, parents and support staff. Furthermore, studies done on pedagogical reasoning of student teachers during the practicum (Phelan, 2009). Indicate that assessment is a strong tool in engaging student teachers in thinking about their work, trying to understand different aspects of their practice, deciding what to make and explaining the reasons for them (Ongeondo, 2009). However, assessment through varied questioning techniques has rarely been done in the Kenyan context.

\subsection{Collaboration and Supervision During Practicum}

Ongeondo (2010) defines collaboration as involving with stake holders for instance cooperating teacher/peers in terms of planning, observation and discussions aimed at learning from experiences during practicum. However, collaboration does not just have two stake holders but it includes cooperating teachers, peers, parents, university, placement schools, language educators and supervisors (Bradfield and Hudson, 2012; Barahmeh, 2016; Duquette and Dabrowski, 2016).

Lieberman and Mace (2008) explain that in the past learning was considered to be an individual affair. However, recently it has become clear that learning is better facilitated when it is more social by involving others doing the same activity or similar practice. They argue that:

Professional learning....is rooted in the human need to feel a sense of belonging and of making a contribution to a community where experiences and knowledge function as part of community property (p. 227).

Research done by Fayne (2007) on the value of supervision on teacher learning during practicum found out that student teachers regard most of their supervisors as playing important roles in supporting their learning. They identified some of their roles to include managing the process of teaching practice, serving as people they could trust with confidential information and giving comments on their teaching that contribute to improvement of their performance.
However, some studies have also shown that assessment focused on supervision threatens student teachers and creates a situation where student teachers pay more attention on pleasing their supervisors than on supporting their students ${ }^{\text {ee }}$ learning (Brandt, 2006; Farrell, 2007; Walkington, 2005). In this regard, Ongeondo and Borg (2011) contend that student teachers on practicum teach plastic lessons to please their supervisors hence curtailing any creativity that student teachers could have wanted to express during teaching practice. This shows that collaboration with stake holders during practicum enhance student teacher learning. In addition, supervisors should endeavor to have a warm relationship with their supervisee and to cultivate a conducive learning environment so that student teachers of English do not strive to please them. In addition, research has indicated that student teachers prefer to be actively involved in post- observation discussions with their supervisors (White, 2007). Supervisors should therefore discuss with their student teachers their classroom practice immediately after the lesson when they can still remember their classroom behaviors which help them to improve their practice (Borg, 2006).

\subsection{Discourse and Conversational Analysis}

Researchers define discourse as stretches of language perceived to be meaningful, unified and purposive. It is language in use, for communication while discourse analysis is the search for what gives discourse coherence (Cook, 2001:6,156; Celce-Murcia and Olshtain, 2000). Accordingly, Jwan and Ongeondo (2011:48) observe that discourse analysis is concerned with the meanings that are got from communication that are verbal, written and nonverbal during interaction. However, Cook (2001) recommend that if we are to find the answer to the problem of what gives stretches of language unity, and meaning, we must look beyond the formal rules operating within sentences and consider the people who use language and the world in which it happens as well.

We therefore define discourse as a coherent stretch of language: sign, written or spoken at length on a subject. Traditionally, language teaching has divided discourse into two major categories, the spoken and the written. Discourse is further divided into four skills of speaking, listening, reading and writing. The boundary between conversation and discourse is a fuzzy one and there are many intermediate cases for example a seminar might come somewhere between the two poles. We can present the difference between the two as a continuum (point A: formal spoken discourse and $\mathrm{B}$ : conversation) and a range of intermediate possibilities in between the continuum.

Context is also an important factor in discourse analysis for instance researchers observe that we are influenced by the situation in which we receive messages, by our cultural and social relationships with the participants, by what we know, what we assume the sender knows, existing knowledge in the receiver of a message, world knowledge, social knowledge are very important in the production and reception of discourse as well as the correct assessment of that knowledge by the sender are all essential for successful communication (Cook, 2001: Celce- Murcia and Olshtain, 


\section{International Journal of Science and Research (IJSR) \\ ISSN (Online): 2319-7064}

Index Copernicus Value (2015): 78.96 | Impact Factor (2015): 6.391

2000). In addition, in a spoken message we use paralinguistic features for instance facial expressions, voice quality and body movement of the speakers (Cook, 2001; Clough, 1992).

Although researchers put forth six dominant approaches to discourse analysis including speech act theory, pragmatics, ethno-methodology, interactional sociolinguistics, ethnography of communication and variation theory (Stubbs, 1983; Tannen, 1989). There are also other approaches to discourse analysis which are equally useful for instance thematic analysis, critical discourse analysis, social cognitive discourse study, political discourse analysis, discursive psychology, conversational analysis, and Laclan and Mouffe ${ }^{\text {ee }}$ s discourse theory (Barker,2003; Jwan and Ong ondo, 2011:49-52).

Discourse analysts are rather vague about what they mean by ,conversation ${ }^{\text {ee }}$ and some use the term to describe any kind of oral interaction (Cook, 2001). Conversational analysis is an approach to the study of natural conversation especially with a view of determining participants ${ }^{\text {ee }}$ method of turn -taking, construction of sequence and utterances across turns, identifying and repairing problems, employing gaze and movement and how conversation works in different conversational settings (Levinson, 1983; Sacks et al, 1974).

Wetherell et al. (2001) argue that researchers using the conversational analysis research approach ought to look at the transcribed data from interview as social action independent of the motivational and psychological characteristics of the interviewee. The essential focus of social discourse analysis is that it aims at revealing social characteristics of a person involved in the interaction. The analytical observations are grounded in the detailed analysis of actual instances of human behavior and not grounded in the institution of the researcher (Jwan and Ongeondo, 2011).

Thus, as Wetherell, et al (2001) explain that a researcher using conversational analysis will focus on the importance of silence of less than a third of a second, the way speakers are able to exchange turns with minimum gaps or overlap between consecutive speakers, the range of exquisite subtle methods participants use to identify and deal with troubles or errors in interaction and the significance of false starts to words, restarts, minor corrections and other range of odd noises and non - lexical sounds people produce in conversational interaction. Hence, conversational analysis focuses on talk-in-interaction as a domain of social activity that is inherently ordered and not reducible to personality of the people talking but how words are designed, where they occurred in an interaction and the underlying organization of the way they are used. In this study, we adopted conversational (ethno-methodological) discourse analysis approach. (Wetherell, et al, 2001; Jwan\&Ongeondo, 2011).

Conversational analysishas several pedagogical implications to the language teacher. These are that language learners should be allowed to maximally interact with language, language teachers should integrate both atomistic activities (bottom -up approach) and holistic activities (top-down approach) during classroom instruction in order for the learners to develop linguistic and communicative competencies. Brumfit (1985) has advanced that teachers should plan systematically in order to realize a balance between ,meaning oriented -fluency ${ }^{\text {ee }}$ and ,form - oriented accuracy. However, many classroom practitioners have undoubtedly continued to teach grammar more or less systematically in traditional way instead of adopting more innovative practices. Although, currently we lack any developed understanding of the most effective way of tackling grammar instruction communicatively, more research and discussions will certainly continue on this question in future.

\subsection{Practicum Length and Discourse Strategies in an English Language Classroom}

Teaching practice certainly remains very important and the pivot of teacher education programmes. However, there is the view that unless teachers are helped to "know how" to engage intelligently in an activity, training institutions will continue to produce teachers who can "t tell how to do it" despite the fact that they have developed within the tradition of teaching. Therefore, it is imperative to endeavour to make the trainees understand the nature of the practical knowledge of teaching to be able to appreciate the way it is acquired and improved (Ongee ondo, 2009). This will reduce the danger of the new teacher reverting to methods by which they were taught in secondary schools and teacher preservice training as learners (Borg, 2006).

English language student teachers should be helped by English language specialists while on practicum in order to "know how" to use correct discourse strategies intelligently in the classroom so that English language learners may learn and develop their language (Ongee ondo, 2009). However, the problem is that there is lack of such intervention in Kenya as has been observed by Barasa (2005), evidence show that some English language student teachers do not get supervised by English subject specialist in teaching practice as they are supervised by lecturers of other subjects for instance science, mathematics and other subjects lecturers.

Kennedy (2010) emphasizes that teachers must encourage their more shy students and discourage their more boisterous ones while learning in the language classroom. Students can be encouraged to participate in the learning process by employing communicative methods of language learning. Skinner (2010) emphasizes that a teacher should have a key teaching skill which is to encourage learners to participate in the learning process without losing their focus of teaching. In addition, learners should be encouraged to give explanations to their peers and elaborations of answers which is important in collaborative group work (Galton, 2007).

Dafftarifard and Alemi (2010) note that gossiping can be used in class as a method of teaching to encourage less fluent students to talk with inspiration. They identify the three types of involvement in conversation: selfinvolvement of the speaker, interpersonal involvement and being involved in what is being talked about. They believe that gossip is the most frequent type of communication and that few people resist doing it. The quality of student learning is closely associated with the quality of classroom 


\section{International Journal of Science and Research (IJSR) \\ ISSN (Online): 2319-7064}

Index Copernicus Value (2015): 78.96 | Impact Factor (2015): 6.391

discourse. Thus, teachers should attach more importance to spoken discourse during classroom interaction. Improve their pedagogical skills in order to improve the quality of classroom to raise the quality of student learning of English language (Zhang, 2008).

Lefstein and Snell (2011) argue that it is difficult to generalize about classroom talk, since different classroom cultures have developed in different national contexts. Schools ${ }^{e e}$ teachers and students differ within contexts,patterns of talk in the same class may vary with changing topics, aims and activities. They also argue that teachers need to understand the importance of talk in teaching and learning, be sensitive to the ways in which conventional discourse norms can be detrimental to pupil thinking and learning and to appreciate the promise and complexity- of dialogic practice.

Teachers ${ }^{\text {ee }}$ instructional discourse improves with a prolonged period of practice. Accordingly, Nathan and Knuth (2003) reported that teachers ${ }^{e e}$ instructional discourse and interactions were gradually promoted over a period of two school years. Their findings indicate that while the teacher had a central role in interactions during the first year, during the second year "a star pattern" emerged with a less evident teacher authority (p.198). Blanton (2002) found that pre service teachers ${ }^{\text {ee }}$ initial beliefs, despite being very influential in the beginning of the teaching practice, could be changed by a reflective study of their classrooms ${ }^{\text {ee }}$ discourse. Discursive reflections could provide teachers ${ }^{\text {ee }}$ with information not only about students ${ }^{\text {ee }}$ learning in Mathematics, but also about how teachers themselves could learn how to teach Mathematics more successfully. This could also be applicable to the teaching of English language. Practicum length can therefore enable student teachers to improve their discourse strategies. However, research in this area has been rarely done in secondary schools in Kenya.

\subsection{How L2 Teachers Modify their Language}

In classroom learning and teaching, a large proportion of time is spent in talking and listening. Being a basic medium of classroom interaction, talking should play a crucial part in the process of learner development (Zhang, 2008). Moreover, the quality of classroom discourse is of great importance because it sets a suitable climate for learning and transforming teacheres expectations for their pupils ${ }^{\text {ee }}$ thinking (Nystrand, 1997).

Skidmore (2000) argue that teachers use two different types of discourse in the classroom: authoritative discourse and internally persuasive discourse. The former means ,someone who knows and possesses the truth instructs someone who is ignorant of it and in errore, while the later refers to more students ${ }^{\text {ee }}$ responses, student self -selection and student topic expansion "e. Thus, it is obvious that in the traditional lessons teachers generally dominate the class talk and students have few opportunities to ask their own questions or generate subtopics (Gutierrez, 1994).A major portion of classroom time in teaching is taken up by teachers talking in front of the class. No matter what teaching strategies or methods a teacher uses, it is necessary to give directions, explain activities, clarify the procedures students should use on an activity, and check students ${ }^{\text {ee }}$ understanding. Ellis (1984:120) observes that:

A large portion of the teacher's total communicative efforts can be taken up with coaxing along the communicative process itself, especially when learners are relative beginners. The teacher has to get the pupilse attention, monitor their understanding by constant checking, clarify, explain, define and when appropriate summarize.

Teachers use varied strategies to make directions and instructions understandable to the learners. Some of these strategies include repetition, speaking slowly, using pauses, changing pronunciation, modifying vocabulary, modifying grammar and modifying discourse by repeating may repeating self or answer their own questions in order to make themselves understood (Richards, 1994). These kinds of modifications in teacher's speech can lead to a special type of discourse which is referred to as teacher talk.

According to Zhang (2008) teacher talk refers to the language used by the teachers in classrooms as opposed to their use of language in other settings for instance at home, at the store, at the doctor's office among others. When teachers use teacher talk they are trying to make themselves as understandable as possible. This is how teachers provide learners with ,comprehensible input ${ }^{\mathrm{ee}}$ (input which is finely tuned to the learners ${ }^{e c}$ level of comprehension (Krashen, 1985) Effective teacher talk may provide essential support to facilitate both comprehension and production of language by the learner.

However, sometimes teachers may develop a variety of teacher talk which would not sound natural outside the classroom especially while teaching low level ESL learners. Walsh (2011) recommends that teachers should raise their awareness of their teacher talk by being more conscious in use of language; noticing the effects of interactional features on learning opportunity, a realization of the importance of using appropriate teacher talk, adjusted not only according to level but also to pedagogic goals. The teacher thus becomes mindful of his/her students by making the right choice at the right time and good interactive decisions (Walsh, 2006; Van Lier, 2000).

\subsection{Teacher Questions}

Research suggests that questioning is one of the most common techniques used by teachers. It has been reported that in some classrooms over a half of class time is taken up with question and answer exchanges. As a result of this second language researchers have examined the contribution of teachers ${ }^{\text {ee }}$ questions to second language learning and concluded that questions play a crucial role in language acquisition for instance questions allow the learner to keep on participating in the discourse and even modify it so that the language used becomes more comprehensible and relevant ( Richards, 1994). Teacher questions can be classified into procedural, convergent and divergent questions. Procedural questions have to do with classroom procedures, routines and classroom management as opposed to the content of learning. 


\section{International Journal of Science and Research (IJSR) \\ ISSN (Online): 2319-7064}

Index Copernicus Value (2015): 78.96 | Impact Factor (2015): 6.391

Convergent questions encourage similar student responses or responses which focus on a central theme. These responses are often short answers, such as "yes" or "no" or short statements. Divergent questions are the opposite of convergent questions and they encourage diverse student responses which are not short answers and which require students to engage in higher level thinking (Richards, 1994; Long and Sato, 1983).

Researches done on teacher questions have identified several issues including the range of questiontypes teachers use, student participation and wait time. Teachers are encouraged to use more of divergent questions than convergent questions to provide opportunities for students to produce and practice the target language. In addition, all students in the classroom should be given opportunity to ask questions or be altered questions by the teacher. The teacher should not only call on those students who can be relied upon to answer the questions or lie in their action zone. Wait time is the length of time the teacher waits after asking a question before calling on a student to answer it, re- phrasing it, directing the question to another student or giving the answer (Richards, 1994).

Rowe (1994) studied the amount of time teachers give learners for them to respond to their questions before repeating the same question or asking a new one, as well as the amount of time between getting a response to the question and reacting to it. She discovered that teachers generally wait for less than a second and when the wait time is increased to three or more seconds, the pattern of communication in the class changes. Students direct more questions to the teacher and to each other and they react to others $^{\text {ee }}$ responses more frequently (Long and Sato,1983, Rowe, 1994; Richards, 1994). Moreover, Stahl et al (2005) concur that if we want students to think about the questions we ask, we need to give them time to think. Giving a few seconds to students to think about their answers makes sense, but in most classrooms, wait times are very short for instance of a second or less. These researchers argue that teachers should increase wait time to three to five seconds which results in high quality student responses, greater participation by all students and an increased student learning (Rowe, 1986, 1994; Kauchak and Eggen, 2011).

However, researchers observe that second language classroom interaction should examine teacher's use of language in relation to stated pedagogical goals. To what extent is language use congruent with pedagogic goals? Were teachers able to promote opportunities for learning by more careful, more conscious language use? Does an awareness of ,wait-time ${ }^{\text {ee }}$ (the delay between a teacher initiation and a learner response) facilitate learner involvement? (Walsh, 2006). Accordingly, Richards and Nunan,(1990) report that some student teachers have been able to examine their use of wait time and have successfully modified its use in teaching.

Long and Sato (1983) observe that student teachers can observe teaching and gain much from studying classroom research of others, research observation and findings. These can act as lens through which to evaluate their instruction. Kauchak and Eggen (2011) argue that effective teachers ask many more questions concerning teaching and learning than less effective teachers do. Thus there should be an equitable distribution of questions in class and involving all students to participate in a lesson. This shows that all students are valued and hence should be involved in the lesson. However, research done by Jones and Dindia (2004) indicated that less effective teachers spend more time lecturing, do a lot of explanation and whenever they ask questions they call on either volunteers or the highest achievers in their classes. Students soon learn that only the „smart ones ${ }^{\text {ee }}$ participate and the other students soon tune out. Hence both learning and motivation suffer (Kauchak and Eggen, 2011). It was therefore imperative to find out how student teachers modify their questioning techniques during the practicum to take care of all learner types.

\subsection{Feedback}

Hattie and Timperly (2007) put forth five major ways that teachers use to provide feedback to their learners including homework, assignments, quizzes and tests, as well as interactive questioning and particularly prompting which is one of the most effective ways of promoting learning. Prompting-providing additional questions and cues when students fail to answer correctly, helps not only the stumped student but also others who may not know the answer. The value of prompting is well documented by research (Good and Brophy, 2008). Less effective teachers tend to turn an unanswered question to another student instead of prompting, asking, for, instance, "can someone else help Claire out?" This communicates that the teacher doesn"t believe Claire is capable of answering and doesn't expect her to do so-not a message we want to send our students.

Providing feedback to learners on their performance is another important aspect of teaching. Feedback can be either positive or negative and may serve not only to let learners know how well they have performed but also to increase motivation and build a supportive classroom climate. In language classrooms, feedback on a student's spoken language may be a response either to the content of what a student has produced or to the form of an utterance. A variety of strategies are available in giving feedback on content for example by acknowledging the correct answer, indicating an incorrect answer, praising, expanding or modifying a student's answer, repeating the studentes answer, summarizing or criticizing (Richards and Nunan, 1990).

In language classrooms, feedback on form is often directed towards the accuracy of what a student says. A number of issues are involved in error feedback. For instance, teacher making decisions about whether learner errors should be corrected, which kinds of learner errors should be corrected, and how learners ${ }^{\text {ee }}$ errors should be corrected (Hendrickson, 1978). Feedback on form can be accomplished in different ways such as asking the student to repeat what she /he has said, pointing out the error and asking the student to selfcorrect, commenting on an error and explaining why it is wrong, without having the student repeat the correct form, asking another student to correct the error and using a gesture to indicate that an error has been made (Harmer, 


\section{International Journal of Science and Research (IJSR) \\ ISSN (Online): 2319-7064}

Index Copernicus Value (2015): 78.96 | Impact Factor (2015): 6.391

1991; ). However, research on how student teachers on practicum provide feedback to learners on their performance is lacking. The objective of the study was to establish practicum length on discourse strategies of student teachers during the practicum.

\section{Methodology}

This study adopted Qualitative research, multiple case study approach. Purposive sampling was used to sample two English language student teachers, one from a Public university (teacher A) and another from a Diploma Teachers college (teacher B) (Creswell, 2009; Jwan and Ongeondo, 2011). The EL student teachers from the public university and the diploma college were on practicum for one term (May-August) and two terms (May-November) respectively. The study was conducted in one of the county schools in Bungoma County, Kenya where student teachers of English had been posted for their practicum.

The raw data was collected through six classroom observations (two for the teacher who was on practicum for one term, and four for the teacher who was on practicum for two terms), use of supervisors ${ }^{\text {ee }}$ notes, informal interviews, audio recording of lessons. As co-operating teachers, we did team teaching with the participants. The participants were informed as to the purpose of the research and that the findings were not to be used to evaluate them as individuals, but rather to describe the activities and the classroom discourse strategies they employed in the English lessons.

As trust grew, it was possible to audio tape their classroom teaching and have informal discussions and to access written feedback from teacher educators. The codes were created from the transcription of the interviews. The raw data collected was transcribed, coded, and analysed descriptively and qualitatively basing on emerging themes. The codes were then grouped into a number of categories and themes for each participant in the study (Jwanand Ongeondo, 2011). The emerging categories and themes were compared with the conceptual framework drawn from the researcherse literature review and were found to be consistent. The researchers then made a preliminary discourse analysis for each student teacher which helped in case and cross-case analysis. The audio tapes for each student teacher were listened to at the end of each class session, summarized and added to the researcher's field notes. The supervisors "e lesson reports (comments) were studied and student teacherse lesson plans were also studied. Each data for each teacher was kept in individual files. The researcher continued later to listen to the audio tapes and helped in partial transcriptions. The source of rigour in this study was trough triangulation of the four data collection instruments (Creswell, 2009).

\section{Findings and Discussion}

\subsection{Findings}

Findings indicated that there were changes in the English language student teachers ${ }^{\text {ee }}$ (A and B) classroom discourse strategies when we compare their discourse strategies at the start of the practicum in May and July 2014 when the practicum ended for the public university student teacher (teacher A). July was the end of the first half of the practicum for the public diploma teachers college student (teacher B) and the second half began in September to November, 2014. The teachers were able to modify their language which enabled English language learners to understand the instructions and directions. They were also able to use different questions and questioning skills and feedback.

Table 1: Student Teachers ${ }^{e c}$ Classroom Discourse Strategies in the First and Second Phase of the Practicum

First Phase of the Practicum Second Phase of the Practicum

\begin{tabular}{|c|c|c|c|}
\hline No & $\begin{array}{l}\text { Discourse } \\
\text { area }\end{array}$ & $\begin{array}{c}\text { Discourse strategy at the beginning of the } \\
\text { practicum(May-August). }\end{array}$ & $\begin{array}{c}\text { Discourse strategies during the second halfof the } \\
\text { practicum (September-November). }\end{array}$ \\
\hline 1 & $\begin{array}{l}\text { Teacher talk } \\
\text { (How } \\
\text { teachers } \\
\text { modify their } \\
\text { classroom } \\
\text { language) }\end{array}$ & $\begin{array}{l}\text { Teacher A } \\
\text {-Began with teacher-centred discourse for instance used } \\
\text { lecture method and speaking at faster pace. } \\
\text {-There was less modification of vocabulary in the first } \\
\text { month. } \\
\text { The teacher improved on his teacher talk. He started by } \\
\text { speaking rather slowly and gradually modified his } \\
\text { grammar at the end of third month } \\
\text { Teacher B } \\
\text {-Just like teacher (A) began with teacher centered } \\
\text { discourse ie lecture method } \\
\text {-at the beginning his speaking pace was slower than that } \\
\text { of teacher (A) but he improved on use of pauses and } \\
\text { modification of his vocabulary. }\end{array}$ & $\begin{array}{l}\text { Teacher B } \\
\text {-Reduced his pace of speaking which allowed } \\
\text { students" comprehension. } \\
\text {-Improved modification of vocabulary replacing } \\
\text { difficult words with more frequently used words. } \\
\text {-He modified his discourse by repeating himself } \\
\text { and answering his own questions unlike in the } \\
\text { first half of the practicum }\end{array}$ \\
\hline 2 & $\begin{array}{l}\text { a) Use of } \\
\text { questions }\end{array}$ & $\begin{array}{l}\text { Teacher A } \\
\text {-In the first month, he used more procedural and } \\
\text { convergent questions with few divergent questions. } \\
\text {-Teacher solicits student response then reacted. Student } \\
\text { participation was limited. } \\
\text {-In the first month of the practicum there was evidence } \\
\text { of balance between divergent and convergent questions } \\
\text { Teacher B } \\
\text {-Like teacher (A) he used more procedural and } \\
\text { convergent questions, but few divergent questions. }\end{array}$ & $\begin{array}{l}\text { Teacher B } \\
\text {-In the second half of the practicum, the teacher } \\
\text { improved student participation in the reading and } \\
\text { speaking lessons by asking divergent (high -level } \\
\text { thinking questions) which deal with content and } \\
\text { reduced the use of procedural and convergent } \\
\text { questions. }\end{array}$ \\
\hline
\end{tabular}

Volume 6 Issue 1, January 2017

www.ijsr.net 


\section{International Journal of Science and Research (IJSR) \\ ISSN (Online): 2319-7064}

Index Copernicus Value (2015): 78.96 | Impact Factor (2015): 6.391

\begin{tabular}{|c|c|c|c|}
\hline & & $\begin{array}{l}\text {-In the third month, he improved on the use of divergent } \\
\text { questions especially in reading and speaking lessons } \\
\text { which promoted classroom interaction. }\end{array}$ & \\
\hline & $\begin{array}{l}\text { b) } \\
\text { Questioning } \\
\text { skills } \\
\text {-Range of } \\
\text { questions } \\
\text {-Student } \\
\text { participation } \\
\text {-Wait time }\end{array}$ & $\begin{array}{l}\text { Teacher A } \\
\text {-At the beginning of practicum, He picked only on a few } \\
\text { students who could be relied upon to answer the } \\
\text { questions correctly. } \\
\text {-In the first month, Wait time was between a half a } \\
\text { second to two seconds but improved in the third month } \\
\text { to between } 2 \text { to } 3 \text { seconds. There was also improvement } \\
\text { in the number of students who answered questions. } \\
\text {-Teacher (B) } \\
\text {-Also picked on a few students in his action zone to } \\
\text { answer his questions and relied upon students he knew } \\
\text { were capable of answering his questions and avoided } \\
\text { those whom he thought had difficulty in answering } \\
\text { especially when there was a supervisor. }\end{array}$ & $\begin{array}{l}\text { Teacher B } \\
\text {-There was a balance of range of questions at the } \\
\text { beginning of second half of the practicum. } \\
\text {-The teacher distributed his questions in the } \\
\text { whole class which improved studentse } \\
\text { participation though teacher action zone still } \\
\text { affected those he chose to answer. } \\
\text {-In the last month of the practicum, he was } \\
\text { relaxed and supervisores presence did not affect } \\
\text { his questioning skills. } \\
\text {-His wait time improved to between } 3 \text { to } 5 \\
\text { seconds towards the end of the practicum and } \\
\text { involved his learners in small group discussions } \\
\text { to answer the questions. Student participation } \\
\text { almost doubled }\end{array}$ \\
\hline 3 & $\begin{array}{l}\text { a) providing } \\
\text { feedback on } \\
\text { content }\end{array}$ & $\begin{array}{l}\text { TeacherA } \\
\text {-In the first month, the teacher acknowledged students } \\
\text { correct answers praised them, he also criticized their } \\
\text { incorrect answers } \\
\text {-In the third month,apart from the above strategies of } \\
\text { acknowledging and praising he also summarized and } \\
\text { repeated students ce correct answers. } \\
\text { Teacher B } \\
\text {-In the first month, he acknowledged students }{ }^{\text {ee correct }} \\
\text { answers, criticized the incorrect answers and repeated } \\
\text { the correct ones } \\
\text {-Apart from the above strategies in the third month, he } \\
\text { modified students answers and also indicated incorrect } \\
\text { answer by use of gestures. }\end{array}$ & $\begin{array}{l}\text { Teacher B } \\
\text {-Towards the end of the practicum in November, } \\
\text { he had improved in the use of feedback provision } \\
\text { strategies: acknowledgement of correct answer, } \\
\text { asking classmates to clap for whoever has } \\
\text { answered correctly seemingly difficult questions, } \\
\text { summarizing the student's correct answer and use } \\
\text { of non-verbal cues to show that the answer is } \\
\text { incorrect or correct. }\end{array}$ \\
\hline & $\begin{array}{l}\text { b)Providing } \\
\text { feedback on } \\
\text { form }\end{array}$ & $\begin{array}{l}\text {-Both Teacher (A) and (B) stopped students at the point } \\
\text { of error and did mini-drills in the first month and wrote } \\
\text { correct answer on the board. } \\
\text {-Teacher (A) repeated the correct sentence with } \\
\text { emphatic stress at point of correction and asked other } \\
\text { students to correct the errors of their classmates in the } \\
\text { third month. }\end{array}$ & $\begin{array}{l}\text { Teacher B } \\
\text {-Apart from the strategies he used in the first half } \\
\text { of the practicum, the teacher pointed out the error } \\
\text { and asked the student to self -correct, asked } \\
\text { another student to correct the error. } \\
\text {-Also asked student to work in groups to correct } \\
\text { the error and gave sentences with errors as their } \\
\text { homework }\end{array}$ \\
\hline
\end{tabular}

(Adapted from Richards, 1994:184; Richards and Lockhard, 2004)

Table 2: Student Teachers Scores During the Practicum (May - August, 2014)

\begin{tabular}{|c|c|c|c|c|c|c|}
\hline $\begin{array}{c}\text { Supervisor's scores for } \\
\text { (Teacher A) }\end{array}$ & $\begin{array}{c}1^{\text {st }} \\
\text { visit } \\
62\end{array}$ & $\begin{array}{c}2^{\text {nd }} \\
\text { visit } \\
64\end{array}$ & $\begin{array}{c}3^{\text {rd }} \\
\text { visit } \\
69\end{array}$ & $\begin{array}{c}4^{\text {th }} \\
\text { visit }\end{array}$ & $\begin{array}{c}5^{\text {th }} \\
\text { visit }\end{array}$ & $\begin{array}{c}\text { Average } \\
\text { score (\%) } \\
\mathbf{6 5}\end{array}$ \\
\hline $\begin{array}{c}\text { Co-operating teacher"s } \\
\text { scores for (Teacher A) }\end{array}$ & 64 & 68 & & & & $\mathbf{6 6}$ \\
\hline $\begin{array}{c}\text { Supervisorec s scores for } \\
\text { (Teacher B) }\end{array}$ & 60 & 64 & 64 & 68 & 70 & $\mathbf{6 5 . 2}$ \\
\hline $\begin{array}{c}\text { Co-operating teacher"s } \\
\text { scores for (Teacher B) }\end{array}$ & 62 & 68 & & & & $\mathbf{6 5}$ \\
\hline
\end{tabular}

Table 3: Student Teacher B- Scores During the Second Half of the Practicum (September to November, 2014)

\begin{tabular}{|c|c|c|c|c|c|c|}
\hline & \begin{tabular}{|l}
$1^{\text {st }}$ \\
Visit
\end{tabular} & \begin{tabular}{|l}
$2^{\text {nd }}$ \\
Visit
\end{tabular} & $\begin{array}{c}3^{\text {rd }} \\
\text { Visit }\end{array}$ & $\begin{array}{l}4^{\text {th }} \\
\text { Visit }\end{array}$ & $\begin{array}{l}5^{\text {th }} \\
\text { Visit }\end{array}$ & $\begin{array}{c}\text { Average } \\
\text { score }(\%) \text {. }\end{array}$ \\
\hline $\begin{array}{l}\text { Supervisor"s scores } \\
\text { for (Teacher B) }\end{array}$ & 68 & 70 & 72 & 76 & 80 & 73.2 \\
\hline $\begin{array}{l}\text { Co-operating } \\
\text { teacheres scores for } \\
\text { (Teacher B) }\end{array}$ & 72 & 78 & & & & 75 \\
\hline
\end{tabular}

3.1.1 Case One: Student Teacher (A): Public University. Table 1 shows that student teacher (A) began his practicum teaching through teacher-centred discourse-lecture method. In his teacher talk, there was less modification of vocabulary where difficult words were to be replaced with more commonly used words. There was evidence of modification of grammar towards the end of the practicum in July, 2014. Also, at the beginning of the practicum in May 2014, the teacher used more procedural and convergent questions and few divergent questions but when the practicum was midway, there was a balance in the use of both convergent and divergent questions. This improved students ${ }^{\text {ce }}$ participation in the lessons. Moreover, student participation in answering of questions was limited at the start of the practicum. The teacher picked on a few students who could be relied upon to answer the questions and avoided those who had difficulty in answering especially when the teacher educators visited them. Also, those students in his action zone were frequently picked on.

Wait-time at the start of the practicum was between a half a second and three seconds. After two supervisions, the teacher improved the wait time to between two and three seconds and this also improved the number of students who responded to the teacher's questions. The teacher provided feedback on content by acknowledging students ${ }^{\text {ee }}$ correct answers and praising them while criticizing them for the incorrect answers. In the mid of the practicum, there was some adaptation to feedback provision. The teacher also 


\section{International Journal of Science and Research (IJSR) \\ ISSN (Online): 2319-7064}

Index Copernicus Value (2015): 78.96 | Impact Factor (2015): 6.391

started repeating students ${ }^{\text {ee }}$ correct answers. On error correction, the teacher began by stopping the student at the point of error and doing mini-drills. He also wrote the correction on the board and repeated the sentence using emphatic stress at the point of correction. Towards the end of the practicum, the teacher picked on other students to correct the errors of their colleagues and also gave them homework assignment(s). The average scores for teacher A by the supervisor and the co-operating teacher at the end of the practicum were $\mathbf{6 5}$ and 66 percent respectively.

\subsubsection{Case Two: Student Teacher (B): Public Diploma Teachers College}

In terms of teacher talk, teacher (B) also began the practicum by teacher-centred classroom discourse, that is, through lecture method. He spoke at a rather faster pace than teacher (A) and used short pauses just like teacher (A). He modified his grammar but there was less modification of vocabulary just like teacher (A) at the end of the first half of the practicum in August. The teacher used different types of questions. The procedural and convergent questions were more evident at the start of the practicum between May and July 2014.

At the end of the first half of the practicum, there was improvement in the use of divergent questions which required students to use their critical thinking skills. This also allowed many students to participate in the lesson as the questions dealt with the content of the lesson. Just like teacher (A) at the start of the practicum, the teacher frequently picked on a few students to answer the questions. This limited the participation of the whole class in the discourse/lesson. But towards the end of the first half of the practicum, after three supervisions by the teacher educators and discussions with the co-operating teacher, he improved in his questioning skills by posing to the whole class and not only to students at the front of the class. There was the same problem that was witnessed on teacher $\mathrm{A}^{\text {ee }} \mathrm{s}$ wait time.

Teacher (B) allowed one to two seconds wait time which limited the number of students who responded to his questions. However, when the first half of the practicum was about to end, there was improvement on wait time to between two to four seconds. This consequently improved the student participation in the classroom discourse- many of them tried to respond to the teacher's questions. Like teacher (A), teacher (B) also provided feedback through praising the student(s) for the correct answers: acknowledging the correct answer and indicating an incorrect answer; and criticizing an incorrect answer. The teacher corrected student's through stopping the student at the point of error and giving the correct answer, writing the correct answer on the board and asking the student to read it aloud. Towards the end of the term in August, the teacher also corrected the errors through asking other students to help in the correction. The average scores for teacher (B) in the first half of the practicum by the supervisor and the co-operating teacher were 65.3 and 65 marks respectively.

\subsubsection{Second Phase of the Study (September to November, 2014)}

The second phase of the study involved only one student teacher (B) whose practicum length was two terms: May to
November 2014. During the second phase of the study, the researcher noted significant gradual changes in the classroom discourse strategies of teacher (B). In the second half of the practicum, teacher (B) considerably reduced the pace of his speech. He spoke reasonably slowly to allow students ${ }^{\text {ee }}$ comprehension when compared to the first half of the practicum. There was also improved modification of his vocabulary and discourse. He could be heard replacing a difficulty word he has used with a simpler one and also repeating himself in order to provide learners with the comprehensible input (Krashen, 1985; Richards, 1994). The teacher also improved in the use of questions. There was a reasonable balance of procedural, convergent and divergent question during the reading and speaking lessons, a good number of divergent (high level thinking) questions were used. This improved the student participation in the lesson and improved on their critical thinking skills. Student participation in the lesson was also enhanced. The teacher started to involve the whole class in answering his questions though there was still some influence of the teacher action zone on the choice of those to answer questions as witnessed by the researcher's classroom observation(s).

There was also a drastic improvement on wait time towards the end of the practicum. It was between three to five seconds. As stated earlier, this prolonged wait-time allowed many students to participate in the lesson through responding to teacheres questions and in class discussions. The teacher provided feedback on the content through strategies he applied in the first half of the practicum but with some additional improvements. Apart from stopping a student at the point of error and doing mini-drills, writing the correction on board and using emphatic stress at the point of correction, and asking other students to correct their classmate s error, he also used gestures to indicate that an error has been made, asked students to work in groups and correct the identified error that had been made, asked students to work in groups and correct the identified error that had been written on the board and also commended on the error and explained why they were wrong. He could also identify students ${ }^{\text {ee }}$ errors and correct them at the end of the lesson. In the second half of the practicum, the average score for teacher B increased to over $70 \%$. The supervisors ${ }^{\text {ee }}$ and the co-operating teacher"s average scores for the student teacher were $73.2 \%$ and $75 \%$ respectively.

\subsection{Discussion}

\subsubsection{Practicum Length and Instructional Discourse Strategies}

The findings gave the implication that the extension of the practicum length of EL student teachers impacted positively on their discourse strategies in English language lessons. However, the short practicum could not provide enough opportunities for the student teachers to develop their discourse strategies. Thus, the short practicum length impacted negatively on the student teachers ${ }^{\text {ee }}$ discourse strategies (teacher A). This finding agrees with researches done by Barasa (2005), Atay (2007) and Blanton, (2002). It can be concluded that the main justification for student teacher (B) who was on practicum for two terms showing improved or better classroom discourse strategies at the second half of the practicum than teacher (A) who was on 


\section{International Journal of Science and Research (IJSR) \\ ISSN (Online): 2319-7064}

Index Copernicus Value (2015): 78.96 | Impact Factor (2015): 6.391

practicum for only one term is the fact that when the practicum progressed, the student teacher who was initially concerned with his own survival in the classroom in the first half of the practicum, began in second term to learn how to facilitate the learning of his own students through effective use of language strategies: teacher talk, questioning skills and providing feedback (Kagan, 1992; Ongondo, 2009).

Nathan and Knuth (2003) reported that teachers ${ }^{\text {ee }}$ instructional discourse and interactions were gradually promoted over a period of two school years. They found out that while the teacher had a central role in interactions during the first year, during the second year "a star pattern" emerged with a less evident teacher authority (p.198). Blanton (2002) found that pre service teacherse initial beliefs, despite being very influential in the beginning of the teaching practice, could be changed by a reflective study of their classroomse discourse. Discursive reflections could provide teachers ${ }^{\text {ee }}$ with information not only about studentse learning in Mathematics, but also about how teachers themselves could learn how to teach Mathematics more successfully. In addition, it may be assumed that the extended practicum made the student teacher to work closely with the co-operating teacher and teacher educators (supervisors).

The teacher educators visited teacher (B) who was on practicum for two terms ten times while teacher (A) who was on the practicum for one term was visited only three times. Also, the co-operating teacher made two observations for teacher (A) while four observations for teacher (B) and discussed his observations with the student teachers. The researchers also audio-taped teacher (A) once and teacher (B) twice. The student teachers and the co-operating teacher listened to the tapes and discussed their classroom discourse with the researcher (Co-operating teacher). It was observed that teacher (A) was supervised by teacher educators who were not English language educators (specialists). According to Barasa (2005) this can hinder student learning as they need educators in their area of supervision. The last supervision was done by a language specialist. The supervisors of teacher (A) never consulted the co-operating teacher and took little time with the student teacher. They seemed to be in a hurry to visit other schools. On the other hand, teacher $\left(\mathrm{B}^{\mathrm{ee}} \mathrm{s}\right)$ ten supervisions were done by English language specialists but P.E. supervisions were done by a P.E. teacher educator.

Many of the teacher educators (supervisors) for Teacher (B) consulted the co-operating teacher and had enough time to discuss with their student teacher in the co-operating teacher's office. This may have also provided more opportunities for teacher (B) to interact with the teacher educators and the Co-operating teacher who were concerned with the student teacher"s use of language both as the goal of the lesson and the means by which this goal was achieved. This support made him to make quick progress from primary concern with his survival to think about how he could facilitate learning among his own students (Borg, 2006). The more the teacher interacted with his English language learners, the more he gained knowledge about his learners and teaching process and thus influenced his discourse decision making strategies (Khales, 2016).

\subsubsection{Collaboration During Practicum}

The student teachers were able to learn by collaborating with cooperating teachers and the supervisors. This finding is the same with the study done by Genc (2016: 680) in Turkey indicated that practicum created a collaborative and cooperative atmosphere for pre-service teachers which they enjoyed a lot.

Before we started the practicum, I had some fears and anxiety; but thanks to my friends and teachers at the schools, I feel much better now, they try to help me and support me in preparing the lessons we frequently exchange our feelings and ideas on activities (Merve).

Collaboration helps student teachers to reflect on their classroom behaviour thus they become more confident and communicative. Research done by Khales (2016) in AlQuids University indicated that reflective dialog eased the difficulties that practicum students faced and increased their self -confidence thus improving ability to communicate with their students and fellow colleagues.

In addition, collaboration help student teachers to know the roles of their supervisors, professional development of supervisor, tensions related to the role of supervisors, sharing ideas and opportunities to learn new ideas. Bradfield and Hudson (2012) did a research in England on the teaching strategies. The research indicated that there are four main teaching strategies adopted by cooperating teachers namely designating facilitators for students ${ }^{\text {ee }}$ learning including teachers, peers, parents, support staff, managing student groups, contexts for learning and using a range of teaching aids and resources.

Another research done recently by Duquette and Dabrowski (2016) Showed that when student teacher collaborate with teacher educators, mentors and peers can provide them with individualized support that facilitate inquiry and reflection during practicum. However, the pre-service teachers also get anxious during the practicum because they are teaching for the first time. In this regard, Barahmeh (2016) did research in Arab American University and the research found that pre-service teachers of English language reflect on the issues that make them anxious for instance classroom management, time management, lesson planning, being observed and fluency in language lessons.

According to Duquette and Dabrowski (2016) research indicated that pre-service teachers are able to describe their situations and reflect individually and collaboratively to analyze and resolve problems related to instruction, discipline and student learning. During collaboration, peer contact should be done using varied ways for better results. For example a research done by Scheeler et al (2004) found that face to face meeting $69.9 \%$, text messaging or email $60.1 \%$, formal university organized discussions forum $15.0 \%$, staffroom discussions with other student teachers $50.3 \%$ and other $11.8 \%$. Ferrier-Kerr (2009) did research in New Zealand and the findings were that student teachers collaborate with their associate teachers in establishing professional relationship during practicum in varied ways

Volume 6 Issue 1, January 2017 


\section{International Journal of Science and Research (IJSR) \\ ISSN (Online): 2319-7064}

Index Copernicus Value (2015): 78.96 | Impact Factor (2015): 6.391

including of supervision, reflection, working as a team, role interpretation and personal connectedness.

\subsubsection{Questioning Techniques and Wait Time}

The student teachers were able to improve their wait time to give the students time to think and answer teachers ${ }^{\text {ee }}$ questions. This finding is in agreement with that of a Study done in Malaysia by Singh and Hashim (2014) which found that teachers in the study sample were not aware of the term wait -time. According to research done by Critelli and Tritapoe (2010) wait time is one of the factors that enhance English language student active participation in high order thinking to divergent questions in which they can actively voice their own opinions and thoughts. However, observations reveal that student teachers of English language mainly asked rhetorical questions which students do not respond to well due to confusion. In addition, convergent questions were found to be effective by enabling students to draw connections to the vocabulary context by student teacher learning several divergent responses. However, research done by Debreli (2016) indicated that practice teaching help teachers to modify their beliefs about language teaching and learning including questioning techniques and wait time this is due to challenges the student teachers face when their theoretical beliefs are confronted with the reality of practice.

\subsubsection{Feedback}

The teachers were able to give their learners immediate feedback which was specific. This agrees with a research done by Scheeler et al (2004) which indicated that feedback given to students should be specific, positive, corrective and immediate for positive impact on behaviour change. Likewise, a recent research done in New Zealand by Starkey and Rawlins (2011) found that student teachers on practicum rated feedback types used by their teachers which included task oriented $39.3 \%$, ego oriented $32.3 \%$, childrens ${ }^{\text {ee }}$ learning $28 \%$ and behaviour management $28 \%$. However, behaviour management was the most preferred by teachers (45\%), task oriented and children learning were the moderately preferred $(41.3 \%)$ while peer feedback was rated low thus minimal impact to learning. However, Genc (2016) did research in Turkey indicated that pre-service teachers on practicum had problems with feedback on practice teaching from mentor teachers who gave general comments for instance good, bad, well done which were not insightful and does not help them improve in teaching effectiveness. Teachers should therefore provide immediate feedback to their students by correcting them but they should not overcorrect as it will discourage learners.

\section{Conclusion}

Practicum enables student teachers to gain skills, knowledge and attitudes they require to be effective teachers. Extension of the practicum length to two or even more terms has a positive impact on English language teaching. It enables student teachers ${ }^{\text {ee }}$ classroom discourse strategies to develop and thus enhance the student-based approach to the teaching learning process. They will pedagogically begin reasoning on how student input and student characteristics play a role in their teaching. This agrees with research done in Kenya by Ongeondo and Borg (2011) findings that English language student teachers who are supervised by English language specialists improve in their pedagogical reasoning skills and develop professionally.

\section{Recommendations}

The study has five recommendations to make for policy. These are:

1) Practicum period for English language student teachers in particular and all student teachers in general should be extended in order to develop their pedagogical effectiveness.

2) English language student teachers should be supervised by English language specialists in order to help them to effectively develop their classroom discourse strategies in English language.

3) There is need for more cooperation and linkages between the university and cooperating schools.

4) The difficulties faced by pre-service teachers on practicum could guide the curriculum designers in modifying or designing teacher education programmes at the universities and teacher training colleges.

5) The Ministry of Education should organize for workshops, seminars and conferences to train secondary school teachers on questioning strategies, wait time and provision of feedback to learners in English language lessons.

\section{References}

[1] Atay, D. (2007). Beginning Teacher Efficacy and the Practicum in an EFL Context, Teach. Dev. 11(2):203219.

[2] Barasa, P. (2005). English Language Teaching in Kenya: Policy, Training and Practice. Eldoret: Moi University Press.

[3] Barameh, M. (2016). A Study of Sources of EFL Student Teacherse Anxiety During their Practicum Experience. European Journal of Research and Reflection in Educational Sciences, 4 (1): 16-25.

[4] Bradfield, K. \& Hudson, P.(2012). Examining Teaching Strategies within Pre-service Teachers ${ }^{e e}$ Practicum Experiences. Paper presented at the $19^{\text {th }}$ International Conference on Learning, London: England.

[5] Borg, M. (2003).Teacher Cognition in Language Teaching: A Review of What Language Teachers Think, Know, Believe and Do. Language Teach, 36:81109.

[6] Borg, S.(2006).The Distinctive Characteristics of Foreign Language Teachers.Language Teaching Research, 10(1): 3-31.

[7] Brumfit, C. (1985) Language, Discourse and Literature: An Introduction.Oxford: OxfordUniversityPress.

[8] Brumfit,C. (1985). Language and Literature Teaching: From Practice to Principle. NewYork: OxfordUniversityPress.

[9] Celce-Murcia, M. \&Olshtain, E. (2000).Discourse and Context in Language Teaching. New York : Cambridge University Press.

[10] Cook, G.(2001) Discourse Oxford: Oxford University Press. 


\section{International Journal of Science and Research (IJSR) \\ ISSN (Online): 2319-7064}

Index Copernicus Value (2015): 78.96 | Impact Factor (2015): 6.391

[11] Cresswell, J.W. (2009).Research Design: Quantitative, Qualitative and Mixed Methods Approaches (3rd Edition).California: Sage.

[12] Daftarifard\&Alemi (2010). Pedagogical Innovations in Language Teaching Methodologies.Journal of Language Teaching and research, 1(6).

[13] Critelli, A.\&Tritapoe, B. (2010).Effective Questioning Techniques to Increase Class Participation.E-Journal of Student Research, 2(1).

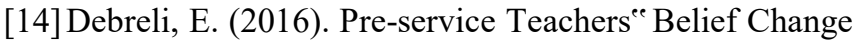
and Practical Knowledge Development During the Course of Practicum. Journal of Education and Training Studies, 4(7)): 37-46.

[15] Duquette, C. \&Dabrowsk, L. (216). A Study of Classroom Inquiry and Reflection Among Pre-service Teachers Candidates. McGill Journal of Education, 51(1): 575-595.

[16]Lefstein\& Snell (2011).Classroom Discourse: the Promise and complexity of Dialogic Practice in Ellis, S., McCartney, E \& Bourne (Eds) (2011) Applied Linguistics and Primary School Teaching. University of London Cambridge: Cambridge University Press, 165185.

[17] Ferrier-Kerr, J. L. (2009).Establishing Professional Relationships in Practicum Settings. Teaching and Teacher Education, 25(6): 790 - 797.

[18]Genc, Z. S. (2016). More Practice for Pre-service Teachers and more Theory for In-service teachers of English language. ELSSEVIER Proedia - Social and Behavioural Sciences 232:677-683.

[19] Good, T. \&Brophy, J.(2008) Looking in Classrooms (10th Edition). Boston: Allyn\&Bacan.

[20] Gudu, B. O., Barasa, P. L. \&Ongeondo,C. O. (2016). Navigating the Learner Related Cultural Dynamics in English Language Teaching and Learning in Secondary Schools in Kenya. International Journal of Current Research, 8(6).

[21] Harmer, J.(1991).The Practice of English Language Teaching.New Edition. New York: Longman.

[22] Hattie, J. \&Timperly, H. (2007). The Power of Feedback. Review of Education Research, 77(1), 81112.

[23] Jwan, O.\&Ongeondo,C.O.(2011).QualitativeResearch: An Introduction to Principles and Techniques. Eldoret: Moi University Press.

[24] Johnson, K.(1995).Understanding Communication in Second Language Classrooms. New York: Cambridge University Press.

[25] Jones, S., \&Dindia, K. (2004).A Meta-analytical Perspective on Sex Equity in the Classroom.Review of Educational Research, 74(4): 443-471.

[26]Kagan, D.M.(1992). Professional Growth among Preserviceand Beginning Teachers.Rev.Educ.Res, 62:129-167.

[27] Kauchak, D. \&Eggen, P.(2011). Introduction to Teaching:Becoming a Professional, 5th Edition. University of North Florida: Pearson.

[28]Khales, B. (2016). The Role of Reflective Dialog in Helping Pre-service Early Childhood Teachers Face Challenges of a Practicum. International Journal of Education and Research,4(9).

[29] Kennedy, M.M. (2010). Against Boldness.Journal of Teacher Education, 61 (1-2): 16-20.
[30] Krashen, S.D. (1985). The Input Hypothesis: Issues and Implications. New York: Longman.

[31]Lieberman, A.(1995). Practices that Support Teacher Development_Transforming Concepts of Professional Learning, Phil Delta Kappan, 76: 591-596.

[32] Levison,S.C.(1983)Pragmatics.Cambridge University Press.

[33] Lieberman, A. \& Mace, P.D. (2008). Teacher Learning: the Key to Education Reform. JournalofTeacherEducation, 59(3):226-234.

[34]Long, M.H.\& Sato, C.J. (1983).Classroom Foreign Talk: Forms and Functions of Teacher Questions. In Salinger, H.W. and Long, M.H. (Eds) Classroom Oriented Research in Second Language Acquisition: 268-85. Massachusetts: Newbury House, Rowley.

[35] Nathan, M. \&Knuth, E.J. (2003).A studyof Whole Classroom mathematics Discourse and Teacher Change. Cognition and Instruction, 21(2): 175-207.

[36] Nystrand, M.(1997).Dialogic Instruction: when Recitation Becomes Conversation Opening Dialogue: understanding the Dynamics of Language and Learning in the English Classroom. New York: Teachers College Press, pp1-29.

[37] Ongeondo, C.O \& Borg, S. (2011). We Teach Plastic Lessons to Please Them "e: The Influence of Supervision on the Practice of English Language Student Teachers in Kenya. Language Teaching Research, 15(4):509-528.

[38] Onge"ondo, C. O. \&Jwan, J. (2009). Research on Student Teacher Learning, Collaboration and Supervision during the Practicum: A literature Review. The University of Leeds, Uk.

[39]Richards, J.C. \&Nunan, D.(1990).Second Language Teacher Education.Cambridge: Cambridge University Press.

[40] Rowe, M. (1986). Wait time: Slowing down may be a way of speeding up. Journal of Teacher Education, 37 (1), 43-50.

[41]Rowe, M.B. (1994) 'Wait time and Reward as Instructional Variables, their Influence onLanguage , LogicandFateControl' Journal of Research on Science Teaching, 11:89-94.

[42] Scheeler, M. C., Ruhl, K. \&MCfee, J. K. (2004). Providing Performance Feedback to Teachers: A Review. Teacher Education and Special Education, 27(4).

[43] Starkey, L. \& Rawlings, P. (2011).Teaching Practicum in $21^{\text {st }}$ Century. New Zealand. RHPF Regional Hub Project Fund.

[44] Skidmore, D. (2000). From Pedagogical Dialogue to Dialogical Pedagogy, Language and Education, 14 (4):283-296.

[45] Skinner, D. (2010). Effective Teaching and Learning in Practice. New York: Continuum International Publishing Group.

[46] Singh, H. K. \&Hashim, C. (2014). The use of wait-time in questioning During Comprehension Lessons by Secondary School Teachers in Selagor. International Journal of Education and Social Science, 1(3).

[47] Walkington, J. (2005) 'Beginning Teachers and Reflective Practice.Asian Pacific Journal of Teacher Education, 33(1).

[48] Walsh, S. (2006). Talking the Talk of the TESOL Classroom.ELT Journal, 60(2). 


\section{International Journal of Science and Research (IJSR) \\ ISSN (Online): 2319-7064}

Index Copernicus Value (2015): 78.96 | Impact Factor (2015): 6.391

[49] Walsh, S. (2011). ELJ Oxford Journals Org. Jean and Alexander Heard Library.

[50] Wetherell, M. et al. (2001) Discourse Analysis. The Open University: Sage Publications.

[51] White, M.(2007)

WorkingwithEmbodimentinSupervision: ASystematicApproach. Amazon: Routledge.

[52]Zhang, Y. (2008). Classroom Discourse and Student Learning.Asian Social Science, 4 (9). 